\title{
Bite marks revisited - evidence for middle-to-late Eocene Basilosaurus isis predation on Dorudon atrox (both Cetacea, Basilosauridae)
}

\author{
Julia M. Fahlke
}

\begin{abstract}
Basilosauridae are cosmopolitan fully-aquatic archaeocete whales, represented by larger Basilosaurus isis and smaller Dorudon atrox in the middle-to-late Eocene Gehannam and Birket Qarun Formations of Egypt (ca. 38-36.5 Ma). Adult and juvenile Dorudon but only adult Basilosaurus are found in these shallow-marine deposits. Lethal bite marks on juvenile Dorudon skulls sparked the idea that adult Basilosaurus invaded calving grounds of $D$. atrox to prey on their young. However, there has been no direct evidence to support this idea. In this study, bite marks on specimens of juvenile $D$. atrox that have previously been described but not assigned to a particular tracemaker are reinvestigated, and additional bone modifications are analyzed. Applying computed tomography (CT), digital surface scanning, and three-dimensional (3D) reconstruction, the juvenile $D$. atrox specimens were digitally placed into the mouth of an adult $B$. isis. Bite marks match the dentition of $B$. isis. Imprints of tooth casts of $B$. isis in modeling clay furthermore resemble bite marks on these $D$. atrox specimens in shape and size. $B$. isis was likely a predator that included juvenile $D$. atrox in its diet. Prey was predominantly captured from a lateral position across the head and sometimes adjusted in the mouth prior to a more powerful bite. Scavenging of $B$. isis on $D$. atrox calves is also possible. The diet of Basilosaurus and dietary differences within the genus resemble those known in modern killer whales (Orcinus orca). B. isis is the only archaeocete known to date that possibly preyed on other cetaceans.
\end{abstract}

Julia M. Fahlke. Museum für Naturkunde - Leibniz-Institut für Evolutions- und Biodiversitätsforschung, Invalidenstraße 43, D-10115 Berlin, Germany julia.fahlke@mfn-berlin.de

KEY WORDS: whales; archaeocetes; bite marks; predation; diet; 3D reconstruction

\section{INTRODUCTION}

Cetaceans evolved from terrestrial artiodactyls around the Paleocene-Eocene boundary (ca. 53.5-56.2 m.y.a.; Gingerich, 2005), with the earliest representatives of archaeocete whales appearing in the early Eocene (Gingerich et al., 2001; Thewissen et al., 2001; Uhen, 2010). The transition from life on land to life in the sea took place within 
Eocene archaeocetes, before modern whales emerged from archaeocetes around the EoceneOligocene boundary, ca. 34 m.y.a. (Fordyce and Barnes, 1994; Fordyce and Muizon, 2001; Gingerich, 2005; Uhen, 2010).

Adaptation to life in the water required thorough morphological and functional changes, including locomotion, sound reception and sound production, reproduction, and, of course, feeding (Luo and Gingerich, 1999; Gingerich, 2003, 2005; Nummela et al., 2004; Uhen, 2004; Gingerich et al., 2009; Fahlke et al., 2011; Thewissen et al., 2011). Isotopic and morphological evidence suggests that the transition to a marine environment was a relatively fast process (Roe et al., 1998; Spoor et al., 2002; Clementz et al., 2006).

\section{Feeding, Tooth Morphology, and Diet in Archaeocetes}

Terrestrial artiodactyls close to the ancestry of whales had bunodont teeth and were most likely herbivorous (Thewissen et al., 2011). A shift to aquatic predation may have been the impetus for cetaceans to abandon land (Gingerich et al., 1983; O'Leary and Uhen, 1999; Uhen, 2007), or this dietary change may have happened after first aquatic adaptations had already occurred (Geisler and Uhen, 2003; Thewissen et al., 2011). Isotope analysis has shown that late early Eocene Pakicetus likely fed in freshwater, that the first marine cetaceans, remingtonocetids and protocetids, appeared by the middle Eocene, and that nearshore foraging was probably retained throughout archaeocete evolution until the late Eocene (Roe et al., 1998; Clementz et al., 2006).

Pakicetids and protocetids retained a protocone and thus some of the grinding function of their molars, but basilosaurids had mediolaterally compressed cheek teeth that lacked grinding surfaces. The cheek teeth of all archaeocete whales are characterized by shearing facets, indicating that archaeocetes chewed their food (O'Leary and Uhen, 1999; Thewissen et al., 2011). Basilosaurus isis, and most likely other basilosaurids, used a single, orthoretractional occlusal movement to puncture, crush, and shear their food, resembling carnivores in this respect. $B$. isis additionally shows unique, very destructive macroscopic tooth wear that includes spalling of flakes of enamel and dentin and implies forceful crushing of large, hard objects, such as mammal bones (Fahlke et al., 2010). Similarly destructive wear has been observed for the protocetid Babiacetus and has likewise been interpreted as an indicator for the consumption of meat (Thewissen et al., 2011).

Stomach contents have been identified for two basilosaurids: Basilosaurus cetoides fed on teleost fish and sharks of up to $50 \mathrm{~cm}$ in length (Swift and Barnes, 1996), and Dorudon atrox preyed on at least two different fish (Uhen, 2004).

\section{Feeding and Diet in Modern Whales}

Modern whales do not masticate. Mysticetes filter-feed, using their baleen as a strainer, and odontocetes use their dentition of numerous homodont teeth to capture their prey and swallow it whole or in large pieces. Both mysticetes and odontocetes employ suction feeding to varying degrees (Werth, 2000; Johnston and Berta, 2010). For the purpose of comparison with archaeocetes that have teeth and show tooth wear, only odontocetes are suitable. Odontocete diet generally consists of fish and squid, and sometimes crustaceans or, in the case of the killer whale (Orcinus orca), marine mammals, sea birds, and sea turtles are included (e.g., Werth, 2000).

Anatomical abbreviations. C, upper canine; c, lower canine; dc, lower deciduous canine; di, lower deciduous incisor; DP, deciduous upper premolar; I, upper incisor; i, lower incisor; $M$, upper molar; $m$, lower molar; $P$, upper premolar; $p$, lower premolar.

Institutional abbreviations. UM, University of Michigan Museum of Paleontology, Ann Arbor, MI, USA; WH, Wadi Al-Hitan, Fayum province, Egypt (specimen presently housed at the University of Michigan Museum of Paleontology).

\section{MATERIALS AND METHODS}

\section{Specimens of Dorudon atrox}

Fossil material of Dorudon atrox studied here is from the Gehannam and Birket Qarun Formations (Bartonian and Priabonian, middle to late Eocene, ca. 38-36.5 Ma) of Wadi Al-Hitan, Fayum Province, Western Desert of Egypt (ca. $150 \mathrm{~km}$ southwest of Cairo). Deposits of these formations are shallow-marine and reflect several regressive and transgressive phases (Gingerich, 1992; Peters et al., 2009). The positions of the $D$. atrox finds in the field are given by Uhen (2004, figure 1).

UM 94814. Partial disarticulated skeleton. Parts examined: skull part comprising the dorsal and posterior sides of the cranium, ventral fragment comprising partial basioccipital, basisphenoid, and pterygoids, left and right maxillary and premaxillary bones, left and right mandibles, left and right audi- 
tory bullae, and cervical vertebrae 1-7. The left mandible shows the alveolus of a fully erupted $\mathrm{m} 1$, and has an erupting $\mathrm{m} 2$ preserved, but $\mathrm{m} 3$ is not visible yet (Uhen, 2000, 2004).

UM 100139. Cranium with the right auditory bulla preserved and only the rostrum missing. M1 is just forming in the crypt (Uhen, 2000, 2004).

UM 94811. Partial skull. Parts examined: dorsal part of the cranium comprising the parietals and frontals, ventral part of the cranium comprising partial pterygoids, the basioccipital, the basisphenoid, the left glenoid process of the squamosal, and partially preserved left and right maxillae and premaxillae. Teeth are missing or isolated. Uhen (2000, 2004) noted the presence of M1 and DP1.

UM 100142. Cranial fragments. Parts examined: disarticulated dorsal and ventral pieces of the cranium comprising the frontals and parietals, and the partially preserved basioccipital, basisphenoid, and pterygoids.

\section{Specimen of Basilosaurus isis}

WH-74. Virtually complete skeleton of an adult individual with a total body length of ca. $16 \mathrm{~m}$ from the shallow-marine deposits of the late Eocene (Priabonian) Birket Qarun Formation of Wadi Al-Hitan, excavated in 1989 and 2005. The find locality is situated about $0.5 \mathrm{~km}$ southwest of UM 94814 and 94811 (cf. Uhen, 2004, figure 1). Parts examined: both mandibles, original cranial parts, and a composite cast of the cranium. The mandibles are largely complete. Skull length is $113 \mathrm{~cm}$. No taphonomic deformation was noted except for a slight mediolateral flattening of the right mandible.

\section{Methods}

Optical inspection and measurements. Uhen (2004) described and interpreted bite marks on specimens UM 94814, 100139, and 94811. These previously described bite marks were re-examined, and information for additional bite marks on these specimens and one additional specimen (UM 100142) was added. Both, the dimensions of the specimens and the bite marks, as well the distances between these marks were measured to 0.1 $\mathrm{mm}$ accuracy using calipers. Additionally, distances between the highest cusps of the upper teeth in the articulated dentition of $B$. isis ( $\mathrm{WH}-74)$ were measured.

Comparative imprints of teeth of Basilosaurus isis. Imprints of fossil teeth in plasticine have previously been used to identify and classify bite marks in bone caused by sharks (Bianucci et al., 2010, and references therein). In a similar approach, I used high-resolution polyester casts of upper teeth of $B$. isis $(\mathrm{WH}-74)$ to create a test sample of imprints for comparisons with bite marks on juvenile $D$. atrox skulls. Layers of modeling clay (Klean Klay) were prepared, measuring about $1 \mathrm{~cm}$ in thickness, and clay surfaces were leveled. Apices of individual tooth casts were then pressed into the clay approximately orthogonally, simulating the ortho-retractional chewing movement (Fahlke et al., 2010).

Digital scanning, 3D surface reconstruction, and fitting of bite marks to teeth. The cranial elements of $\mathrm{WH}-74$ that had been disarticulated before burial were molded and casted, and the casts reassembled into a whole cranium. The original cranial parts and mandibles as well as the cast of the cranium were CT scanned (GE HD-750) in the Department of Radiology at the University Hospital, University of Michigan. In-plane resolution was $0.879 \mathrm{~mm}$, and slice thickness was $0.625 \mathrm{~mm}$. Three dimensional surfaces were extracted from image stacks using Amira 5.0 at the University of Michigan Museum of Paleontology and further prepared in Materialise Magics 14 at the University of Michigan 3D Lab. Slight flattening of the right mandible was removed in Autodesk 3ds Max 2010, and the mandibles were aligned to the cranium using Materialise 3-Matic 4.4 (University of Michigan 3D $\mathrm{Lab}$ ) in the best dental occlusion possible.

Above-listed crania or partial crania of juvenile $D$. atrox that show previously described bite marks (Uhen, 2004) and other bone modifications were scanned using a Creaform Handyscan REVscan surface scanner and VXelements software (University of Michigan 3D Lab). Surfaces were further processed in Materialise Magics and 3-Matic.

The 3D surfaces of the individual cranial remains of $D$. atrox were then placed between the jaws of the skull model of $B$. isis (WH-74) in Materialise 3-Matic. Experimentally, they were positioned in such way that teeth of $B$. isis touched the bite marks without other surfaces intersecting. The respective best fit is documented and described in this paper.

\section{RESULTS}

\section{Bone Modifications on Specimens of Juvenile Dorudon atrox}

UM 94814. Uhen (2004) noted the presence of three circular to oval depressions of 5-7 mm diameter across the frontal shield (white circles in Figure 1.1-2). Two of these are situated to the left of 
the dorsal midline and lie approximately $15 \mathrm{~mm}$ apart (measured from center to center of the depressions); the third is separated from the second one by approximately $49 \mathrm{~mm}$ and situated on the dorsal midline. Uhen's (2004) observation and measurements are confirmed here, and the abovedescribed bone modifications are numbered 1-3 from left to right accordingly. Modifications 2 and 3 each have a small raised mound in the depression center.

There are several additional bone modifications. From modification 3 , a scrape of $5.3 \mathrm{~mm}$ width extends anteriorly and dextrally for $20.8 \mathrm{~mm}$ (arrow in Figure 1.2), deepening in that direction, and ending in another small, oval depression (Figure 1.2, bone modification 4). Bone modification 4 is accompanied by a shallower depression of the same shape, ca. $10 \mathrm{~mm}$ anteromedial to it (Figure 1.2, bone modification 5). Furthermore, there are bone modifications anterior to modifications 1-5. The left side of the frontal is damaged anterior to the orbit, missing the supraorbital process. In dorsal view, the fracture shows a curved outline of $36.5 \mathrm{~mm}$ length (Figure 1.2, bone modification 6) and is contiguous with an oval hole with irregular outline that penetrates the bone at the suture between the left frontal and nasal. This hole is ca. $48 \mathrm{~mm}$ wide mediolaterally and measures $20.5 \mathrm{~mm}$ in maximum anteroposterior diameter (Figure 1.2, bone modification 7). On the right side, the anterior portion of the frontal has another hole of $37.5 \mathrm{~mm}$ anteroposterior length with a curved outline showing three lobes on its medial side (Figure 1.2, bone modification 8). Modifications 7 and 8 lie $48.4 \mathrm{~mm}$ apart.

Most of the ventral side of the cranium is missing so that the view into the braincase is open. The preserved ventral part of the cranium of UM 94814 is severely damaged on the left, right, and anterior edges, showing an irregular, curved breakage line on the latter.

Both the left and right mandibles of this specimen lack their condylar and coronoid processes. The breakage lines extend from just anterior to the coronoid process to the level of the erupting $\mathrm{m} 2$ on both sides. Both mandibles are further broken off anterior to the alveoli of di3 and dc, respectively.

Further damage noted on UM 94814 includes the following: the right parietal is damaged laterally, anterior to the zygomatic arch. The maxillae show some damage on the ventral side. Maxillae and premaxillae are disarticulated, and both premaxillae show damage in their anteriormost parts. The auditory bullae are broken off, and only their ventral sides are preserved.

UM 100139. Uhen (2004) noted the presence of a single, conical bite mark that is oval in outline on the anterior portion of the right frontal. This finding is confirmed here (Figure 1.3, bone modification 1). New measurements show that this bone modification is $13.4 \mathrm{~mm}$ deep, the long axis of the outline measures $16.4 \mathrm{~mm}$, and the short axis is $8.8 \mathrm{~mm}$ long.

In addition to bone modification 1, there is an angular fracture where the left frontal is broken off anterior to the orbit. The square described by this angle is $21.6 \mathrm{~mm}$ long anteroposteriorly and ca. 20 $\mathrm{mm}$ wide mediolaterally (Figure 1.3, bone modification 2). The left side of the basicranium is sheared off, and the left auditory bulla is missing (Figure $1.3,1.4)$. There is a bilobate, $32.7 \mathrm{~mm}$ long breakage line on the ventral side of the cranium, affecting the occipital (Figure 1.4, bone modification 3), and the right pterygoid is also damaged. The pterygoid naturally forms a vertical wall running in an oblique anteroposterior direction, but it is interrupted in this specimen by an incision with a curved outline, measuring $26.6 \mathrm{~mm}$ in dorsoventral direction and ca. $26 \mathrm{~mm}$ in anteroposterior direction (Figure 1.3, bone modification 4). Additionally, several holes penetrate the bone on the lateral sides of the cranium.

UM 94811. According to Uhen's (2004) observations, a single bite mark is present on the left side of the frontal shield of this specimen, forming a shallow, $6 \mathrm{~mm}$ deep depression with an oval, slightly bilobate outline. The presence of this bone modification is confirmed. Its long axis measures $33.8 \mathrm{~mm}$, and the short axis is $12.2 \mathrm{~mm}$ in maximum length (Figure 1.5, bone modification 1). The frontal is broken off at the posterolateral margin of bone modification 1 . In addition, another modification on the posterior portion of the right frontal is observed, ca. $63 \mathrm{~mm}$ across the skull from the center of bone modification 1. The frontal is broken off here, and a triangular, $11 \mathrm{~mm}$ long incision in the otherwise straight break line is present (Figure 1.5, bone modification 2).

The ventral part of the cranium of UM 94811 shows irregular breakage posterior to the pterygoid sinuses, with the auditory bullae and the occiput missing. The maxillae and premaxillae show additional damage.

UM 100142. This specimen has not been included in the report of bite marks by Uhen (2004). However, UM 100142 does show a set of bone modifi- 


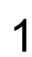

1

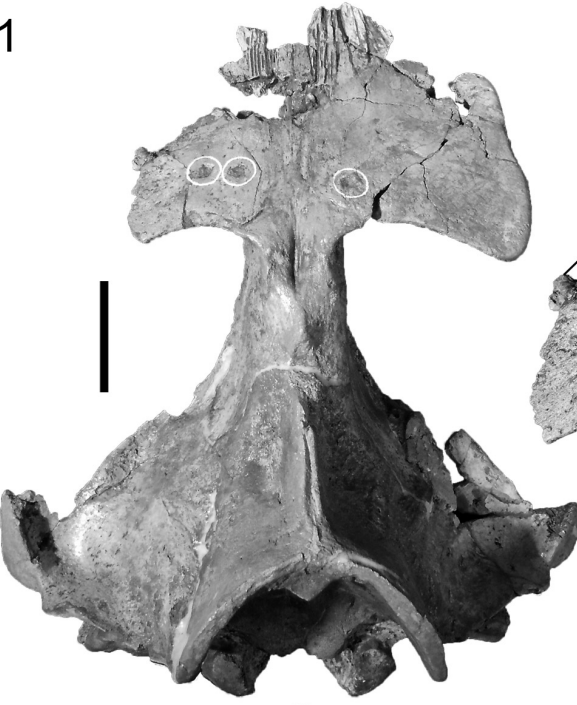

3

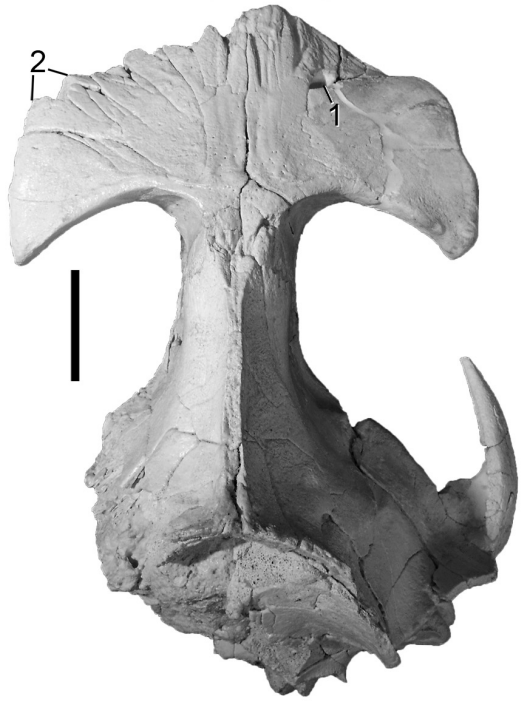

5

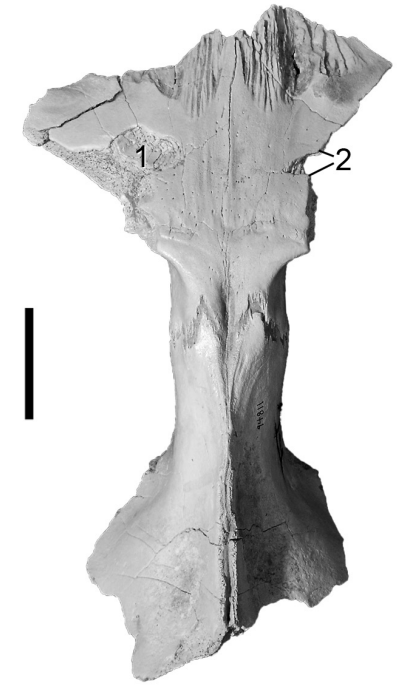

2

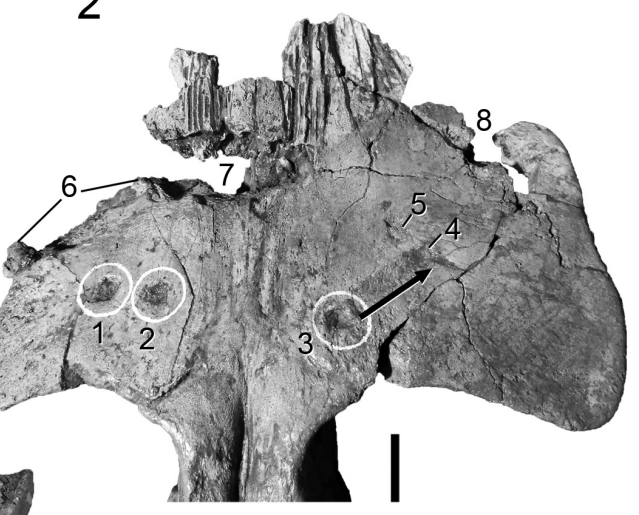

4

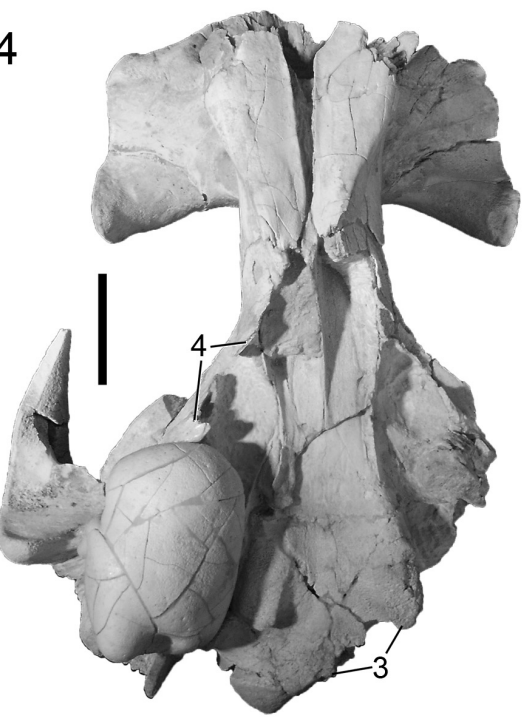

6

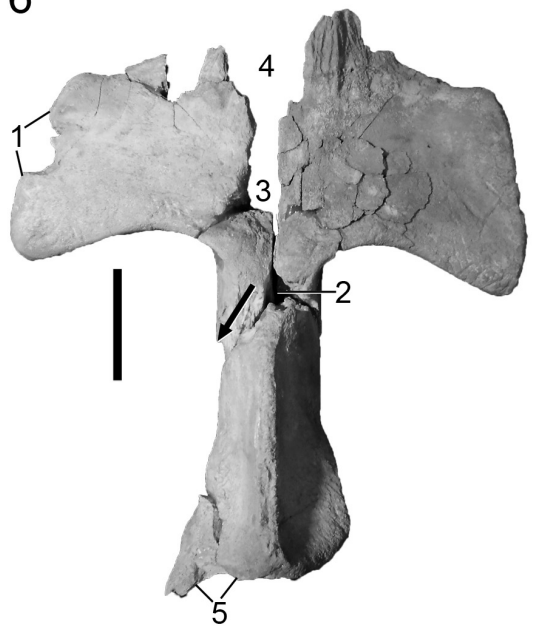

FIGURE 1. Cranial remains of juvenile Dorudon atrox with bone modifications. 1.1, UM 94814 in dorsal view; 1.2, same, close-up of frontal shield with bone modifications; 1.3, UM 100139 in dorsal view; 1.4, same in ventral view; 1.5, UM 94811 in dorsal view; 1.6, UM 100142 in dorsal view. Scale bar equals $5 \mathrm{~cm}$ in 1.1 and 1.3-1.6. Scale bar equals $2 \mathrm{~cm}$ in 1.2 . 


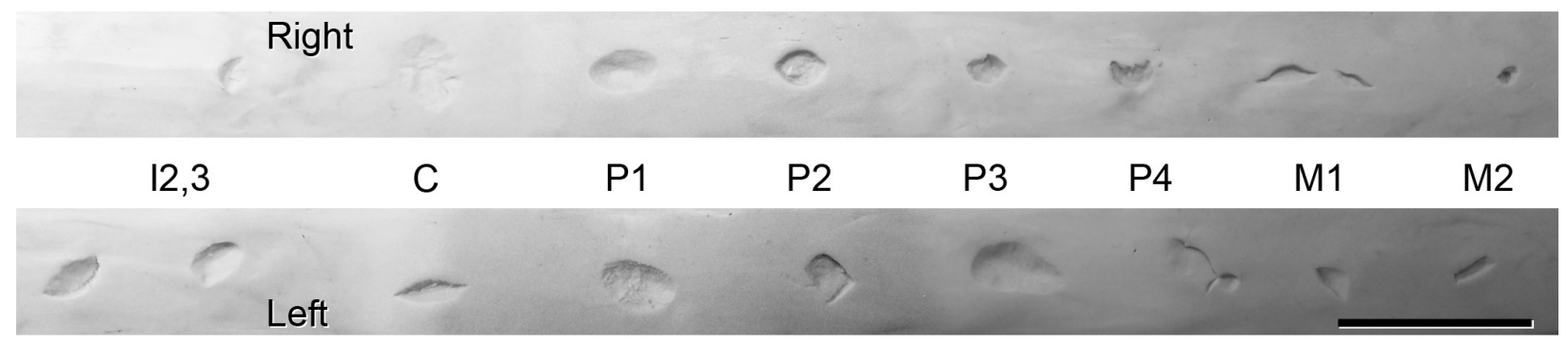

FIGURE 2. Comparative tooth marks of Basilosaurus isis. Imprints in modeling clay created using polyester casts of the upper teeth of specimen $\mathrm{WH}-74$. Scale bar equals $5 \mathrm{~cm}$.

cations. There is a semicircular, somewhat irregular incision of $27 \mathrm{~mm}$ length on the lateral side of the left frontal, right above the orbit (Figure 1.6, bone modification 1). Additionally, there are two semicircular-to-circular holes with irregular margins located on the dorsal side of the cranium. One of these holes is situated on the dorsal midline suture, approximately at the suture between the frontals and parietals, and measures $15.8 \mathrm{~mm}$ in anteroposterior and $14.9 \mathrm{~mm}$ in dextral-to-sinistral diameter (Figure 1.6, bone modification 2). The other hole is located anterolateral to bone modification 2 and is $20.1 \mathrm{~mm}$ wide (Figure 1.6, bone modification 3). It opens anteriorly into a wide gash separating the left and right frontal bones, and ending in a semicircular incision (Figure 1.6, bone modification 4). From bone modification 2, a scrape of about $12 \mathrm{~mm}$ width extends ventrally on the left side of the cranium, approximately along the frontal-parietal suture (arrow in Figure 1.6). The anterior margin of the frontals is also damaged.

The basicranium of this specimen is not preserved. Damage on the posterior part of the skull includes a semicircular irregularity (Figure 1.6, bone modification 5), and the outline of the posterior end of the specimen resembles that of UM 94811 (Figure 1.6, cf. Figure 1.5). The preserved ventral part of the cranium of UM 100142 is broken on its left side.

\section{Comparative Imprints of Teeth of Basilosaurus isis}

The overall dental formula of Basilosaurus isis is 3.1.4.2/3.1.4.3. Upper and lower molars and $\mathrm{P} / \mathrm{p}$ 2-4 are double-rooted and high-crowned, with a central cusp and anteroposteriorly aligned accessory denticles. The molars are generally smaller, more closely spaced, and lower-crowned than the premolars.

Imprints produced using casts of individual teeth of $B$. isis $(\mathrm{WH}-74)$ and modeling clay are shown in Figure 2. Polyester and clay do not have the same physical properties as tooth enamel and dentin, or bone cortex, respectively. Accordingly, it would be surprising if this experiment yielded exact duplicates of the bone modifications observed on the museum specimens of $D$. atrox pictured in Figure 1. Comparison of shapes and sizes between actual bone modifications and imprints, however, can provide indications as to whether $B$. isis could possibly have been the producer of the previously identified bite marks (Uhen, 2004) and additional modifications observed.

Generally, various shapes and sizes of actual bone modifications could be mimicked by clay imprints. Small, oval marks, with or without a raised mound in the center of the depression, similar to bone modifications 1-5 on UM 94814 (Figure 1.12 ), are produced by pointed, unworn or slightly worn central cusps of premolars and molars. This is demonstrated by imprints of the right P2-P4 and M2 of WH-74 (Figure 2). These marks measure about a centimeter in length and can also be more angular when the teeth producing them are slightly more worn, as is seen in the imprint of the left P2 of $\mathrm{WH}-74$, which resembles bone modification 2 on UM 94811 (Figure 1.5).

Two marks located within a few millimeters of each other, like bone modifications 2 and 3 , or bone modifications 4 and 5 on UM 94814, can potentially be produced by two cusps of a single tooth, as the imprint of the right M1 shows (Figure 2). However, the right $\mathrm{M} 1$ of $\mathrm{WH}-74$ is too heavily worn to produce oval imprints, and only its buccal enamel ridges left impressions in the clay.

Single, deep, oval imprints with long axes of about $15-20 \mathrm{~mm}$ and sharp edges, resembling bone modification 1 on UM 100139 (Figure 1.3), are produced by slightly to moderately worn monocuspid incisors or canines, as is demonstrated by the imprints of the left $\mathrm{I} 2$ and $\mathrm{C}$ of $\mathrm{WH}-74$ (Figure 2). Sharp edges are caused by enamel ridges. 
More angular marks of about the same size, like bone modifications 2 and 3 on UM 100142 (Figure 1.6), might also be produced by incisors or canines, respectively, or by the central cusps of heavily worn molars, as the imprints of the left M1 and M2 of WH-74 show (Figure 2). Upper first premolars that are monocuspid like incisors and canines seem to produce oval imprints of the same size, but with a more rounded outline and less sharp edges.

Marks with an irregular or bilobate outline, like bone modifications 6-8 on UM 94814, and bone modification 3 on UM 100139 (Figure 1.1-2 and 1.4 , respectively), were most likely produced by the impression of the central cusp and one or more accessory denticles of a premolar. This is convincingly demonstrated by the imprint of the left P4 of WH-74 (Figure 2).

Large, shallow depressions with an oval outline or shaped like the number eight, like bone modification 1 on UM 94811 (Figure 1.5), are produced by heavily worn, rounded large teeth, such as the left P3 of WH-74 (Figure 2).

Generally, it must be taken into consideration that a single tooth can produce different shapes of imprints, depending on the bite force applied. It cannot be ruled out that, e.g., the cusps of a slightly worn premolar can produce small, oval imprints when small forces are applied, but actually penetrate bone causing a large mark with a curved or bilobate outline when large forces are applied.

\section{Digital Fitting of Bone Modifications to the Dentition of Basilosaurus isis}

The juvenile $D$. atrox specimens UM 94814, 100139, 94811, and 100142 were digitally fitted into the open jaws of the skull model of the adult $B$. isis ( $\mathrm{WH}-74)$. It must be taken into account that it is very unlikely that - if predation took place - it was this particular individual of $B$. isis that preyed on these particular individuals of $D$. atrox. Therefore, an identical match of teeth and bone modifications cannot be expected, and what is aimed for here is the best possible fit.

UM 94814. This specimen fits best into the mouth of $B$. isis when it is placed with its left and anterior portions facing the throat and its right side and posterior portion facing toward the tip of the rostrum of $B$. isis. This position suggests that UM 94814 was bitten across the skull from the front left, with the right side of the dentition (Figure 3.1). The bone modifications on the dorsal side of UM 94814 were presumably caused in two or even three phases. As shown in Figure 3.2 (cf. Figure 1.2), the central cusp and an additional denticle of the right P3 may have produced bone modifications 1 and 2 . Simultaneously, the right P2 could have caused bone modification 3 , given the tooth had a pointed cusp like that of $\mathrm{WH}-74$. The scrape that extends from modification 3 toward modification 4 indicates sliding of UM 94814 in the mouth. This scrape also indicates that bone modification 4 has been caused by the same tooth as bone modification 3 , namely the right P2. Modifications 4 and 5 are so close together that they may well have been inflicted by two cusps of the same tooth.

In order to explain bone modifications 6, 7, and 8 on UM 94814, further adjustment of UM 94814 in the same direction as the abovedescribed scrape is considered here, followed by a more forceful bite that finally penetrated the bone (Figure 3.3, cf. Figure 1.2). Bone modification 6 may have been produced by the right P4. Bone modification 7 was potentially caused by the right P3 that had probably produced modifications 1 and 2 earlier. Bone modification 8 was likely produced by the right $\mathrm{P} 2$, the same tooth that is potentially responsible for modifications 3-5 and the scrape.

The distance between bite modifications 1 and 3 approximates the distance between the centers of modifications 7 and 8 (63.3 and ca. $65 \mathrm{~mm}$, respectively). These values lie within the values recorded for distances between the central cusps of $\mathrm{P} 2$ and $\mathrm{P} 3$ of $B$. isis (WH-74; $63.0 \mathrm{~mm}$ on the left and $73.1 \mathrm{~mm}$ on the right side).

Damage of the ventral side of the cranium and the mandibles of UM 94814 may correspond to the impact of the right lower cheek teeth, if the cranium is positioned as shown in Figure 3.

Another possible way to place UM 94814 in the mouth of $\mathrm{WH}-74$ is to fit the teeth of the left upper tooth row of $B$. isis with the bone modifications. This positioning places the whole skull of UM 94814 inside the mouth with the right tooth row of $B$. isis posterior to the basicranium, implying decapitation of the juvenile. However, a decapitation scenario is unlikely, since all cervical vertebrae of UM 94814 are preserved and only show minor, possibly post-mortem damage (broken neural and transverse processes).

UM 100139. This specimen fits best in the mouth of $B$. isis when it is placed with its left side facing the throat and its right side facing the rostrum of $\mathrm{WH}-74$, simulating a bite across the frontal shield from the left side (Figure 4.1) In this position, the left I 3 could have caused bone modification 1 , and the left $\mathrm{C}$ could have inflicted bone modification 2 (Figure 4.2, cf. Figure 1.3). The distance between 

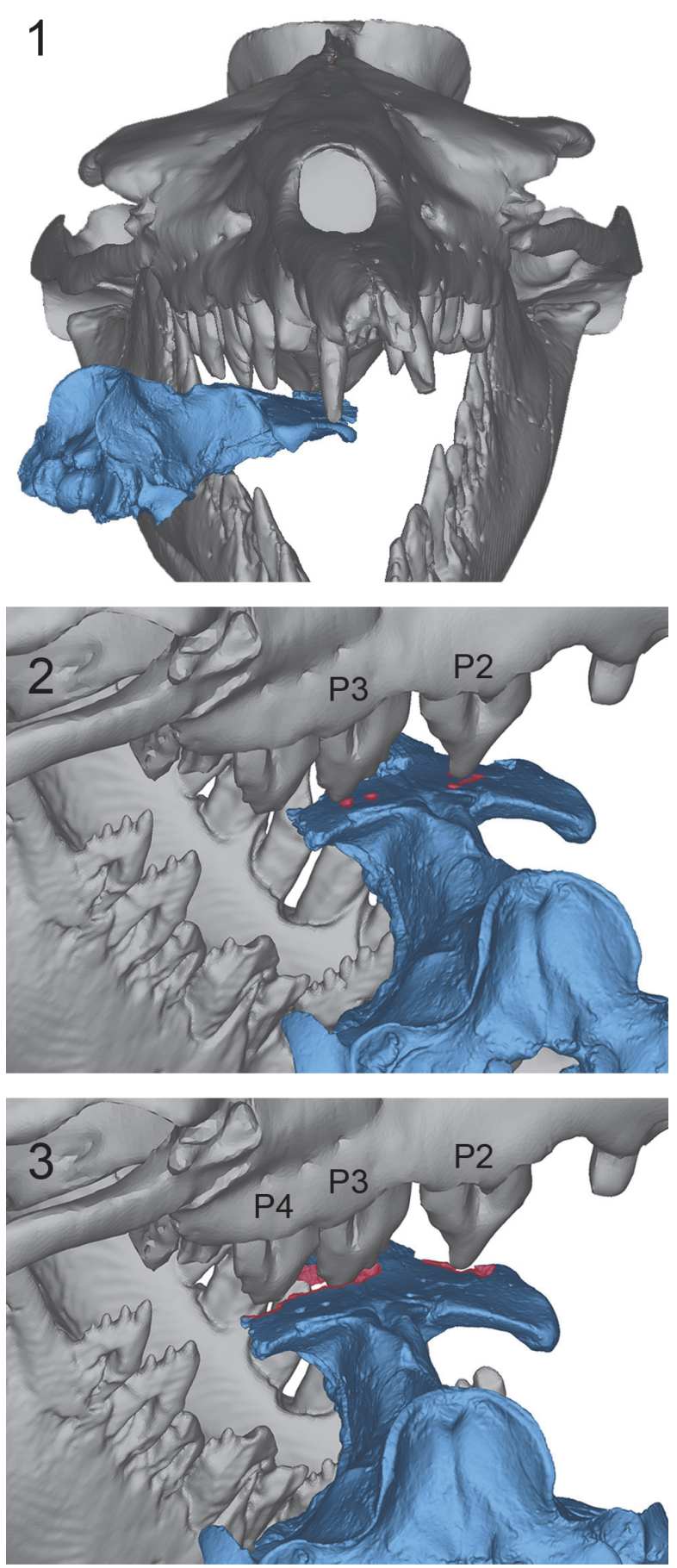

FIGURE 3. Placement of 3D digital surface model of juvenile Dorudon atrox specimen UM 94814 (blue) into the mouth of an adult Basilosaurus isis (reconstruction of $\mathrm{WH}-74$, gray). 3.1, best fit of teeth to bone modifications in frontal view; 3.2, same in right lateral view; 3.3, same after readjustment in the mouth in right lateral view. Directions are given with respect to the skull of $B$. isis; bone modifications are highlighted in red. modifications 1 and 2 (108.5 mm) approximates the distance between the left $\mathrm{I} 3$ and $\mathrm{C}$ of $\mathrm{WH}-074$ $(117.5 \mathrm{~mm})$. This is the largest distance measured between two adjacent teeth in the complete upper dentition of $\mathrm{WH}-74$. Furthermore, the described position of UM 100139 allows for the right $\mathrm{c}$ to inflict bone modification 4 (Figure 4.2, cf. Figure 1.4).

Obvious damage to this specimen includes the sheared left side of the basicranium. The shape of this damage fits well the curvature of the jaws on the left side of $\mathrm{WH}-74$, with the left $\mathrm{p} 2$ and 3 involved in the shear (Figure 4.3-4). The left p2 might consequently have caused bone modification 3 (Figure 4.4, cf. Figure 1.4). This scenario gives an implication for the decapitation of a juvenile $D$. atrox by $B$. isis. However, if decapitation took place, it cannot be determined whether it occurred before or after the bite across the skull.

UM 94811. The bone modifications on UM 94811 can best be correlated with the teeth of $B$. isis when the specimen is placed in the open mouth in such way that its left side faces toward the throat and its right side faces toward the rostrum, again depicting the scenario of a bite across the frontal shield from the left side (Figure 5.1). In this position it is possible that bone modification 1 was caused by the left P3, given the tooth was as worn as it is in $\mathrm{WH}-74$. Bone modification 2 could have been inflicted by the left P2 (Figure 5.2, cf. Figure 1.5). The distance between modifications 1 and 2 (ca. $63 \mathrm{~mm}$ ) is in accordance with the distances between the central cusps of P2 and P3 in $\mathrm{WH}-74$ $(63.0 \mathrm{~mm}$ on the left and $73.1 \mathrm{~mm}$ on the right side). Additionally, some of the breakage of the left anterior frontal of UM 94811 might have been inflicted by the left P4.

Breakage on the ventral part of the cranium of UM 94811, posterior to the pterygoid sinuses, corresponds well with the position of the right lower teeth of $\mathrm{WH}-74$, if the specimen is positioned as shown in Figure 5.1.

UM 100142. The bone modifications on UM 100142 can best be fit to the teeth of $B$. isis when the specimen is placed in the mouth with its anterior part facing the throat and its posterior part facing the rostrum of $\mathrm{WH}-74$, suggesting a bite from the front (Figure 6.1). In this position, the left upper teeth of $B$. isis contact the dorsal side of the $D$. atrox skull approximately along its midline suture. The left $\mathrm{C}$ may have produced either bone modification 2 or bone modification 3 , or both in the case of readjustment of UM 100142 in the mouth. The left P1 might have inflicted bone modification 4 

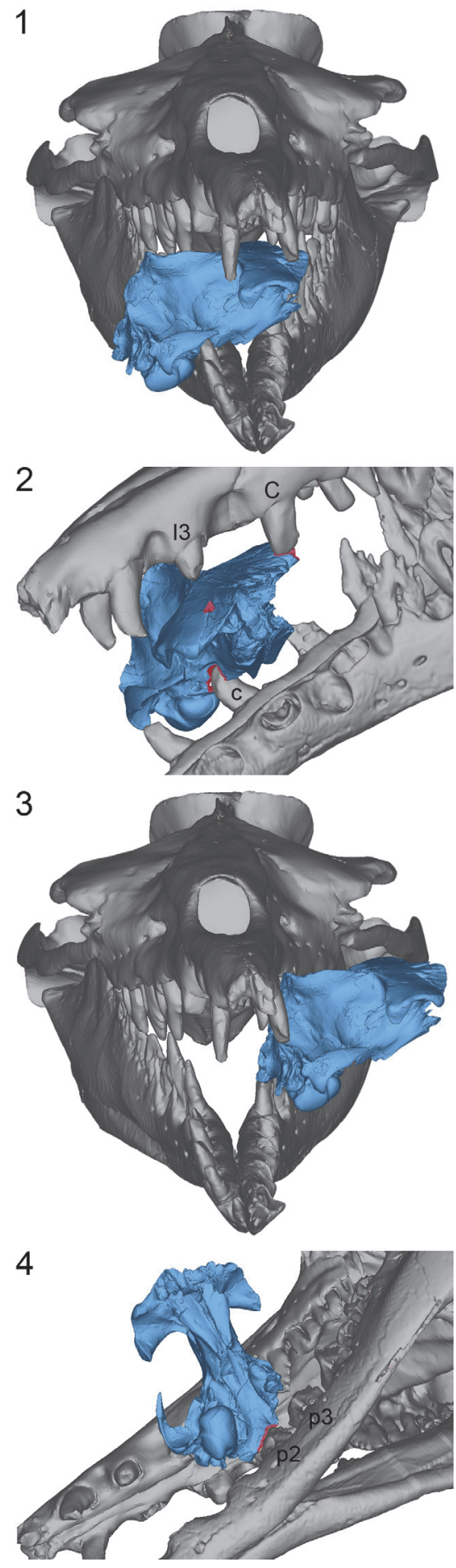

FIGURE 4. Placement of 3D digital surface model of juvenile Dorudon atrox specimen UM 100139 (blue) into the mouth of an adult Basilosaurus isis (reconstruction of $\mathrm{WH}-74$, gray). 4.1, best fit of teeth to bone modifications in frontal view; 4.2, same in left lateral view; 4.3, possible decapitation position of UM 100139 in frontal view; 4.4 , same in ventral view. Directions are given with respect to the skull of $B$. isis; bone modifications are highlighted in red.
(Figure 6.2, cf. Figure 1.6). The right P1 simultaneously fits bone modification 1 . The scrape along the left frontal-parietal suture of UM 100142 could potentially have been caused by the left $C$, if it produced bite mark 2, or, in the case of readjustment, by the right $\mathrm{C}$. Bone modification 5 lies directly underneath the right 13 , a tooth that is missing in $\mathrm{WH}-74$, but, if present, may have produced this modification (Figure 6.3, cf. Figure 1.6).

In the above-described position, breakage on the left side of the ventral part of the cranium, mainly the pterygoid, might be attributed to either the impact of the right $\mathrm{c}$ or $\mathrm{p} 1$.

\section{DISCUSSION}

\section{Source of Bone Modifications}

This study demonstrates that different sizes, depths, and outlines of bone modifications seen on cranial remains of juvenile Dorudon atrox resemble imprints of teeth of an adult Basilosaurus isis. Bite mark morphology is dependent on tooth position, degree of wear, and possibly bite force. Furthermore, the spacing of the teeth and of the cusps of individual teeth of an adult $B$. isis matches that of the bite marks on the crania of $D$. atrox juveniles, as was shown by digitally fitting the bone modifications to the dentition of $B$. isis.

Almost all morphologies of bone modifications observed on the juvenile specimens studied here could be reproduced by making imprints of $B$. isis tooth casts in modeling clay. However, a few bone modifications, like the sheared-off basicranium of UM 100139 and some of the breakage including bone modification 4 on UM 100142, could not be reproduced. These bone modifications either show ragged edges or sharp breaks, and it cannot be excluded with certainty that these particular bone modifications were produced by post-mortem and/ or post-diagenetic mechanical manipulation, e.g., breakage during excavation. Therefore, although the shape of the damage on the back of the cranium of UM 100139 fits the curvature of the tooth row of $B$. isis (Figure 4.4), interpretations involving this damage, namely a potential decapitation of a juvenile $D$. atrox, must remain speculative.

The shape of some marks, like bone modifications 1-5 on UM 94814 (Figure 1.2), implies that they have been caused by pointed teeth, which led Uhen (2004) to suggest crocodiles with conical teeth as the tracemaker. Large crocodiles like Crocodilus megarhinus (upper and lower jaws described and figured as $C$. articeps by Andrews, 1906) were indeed present in the middle to late 

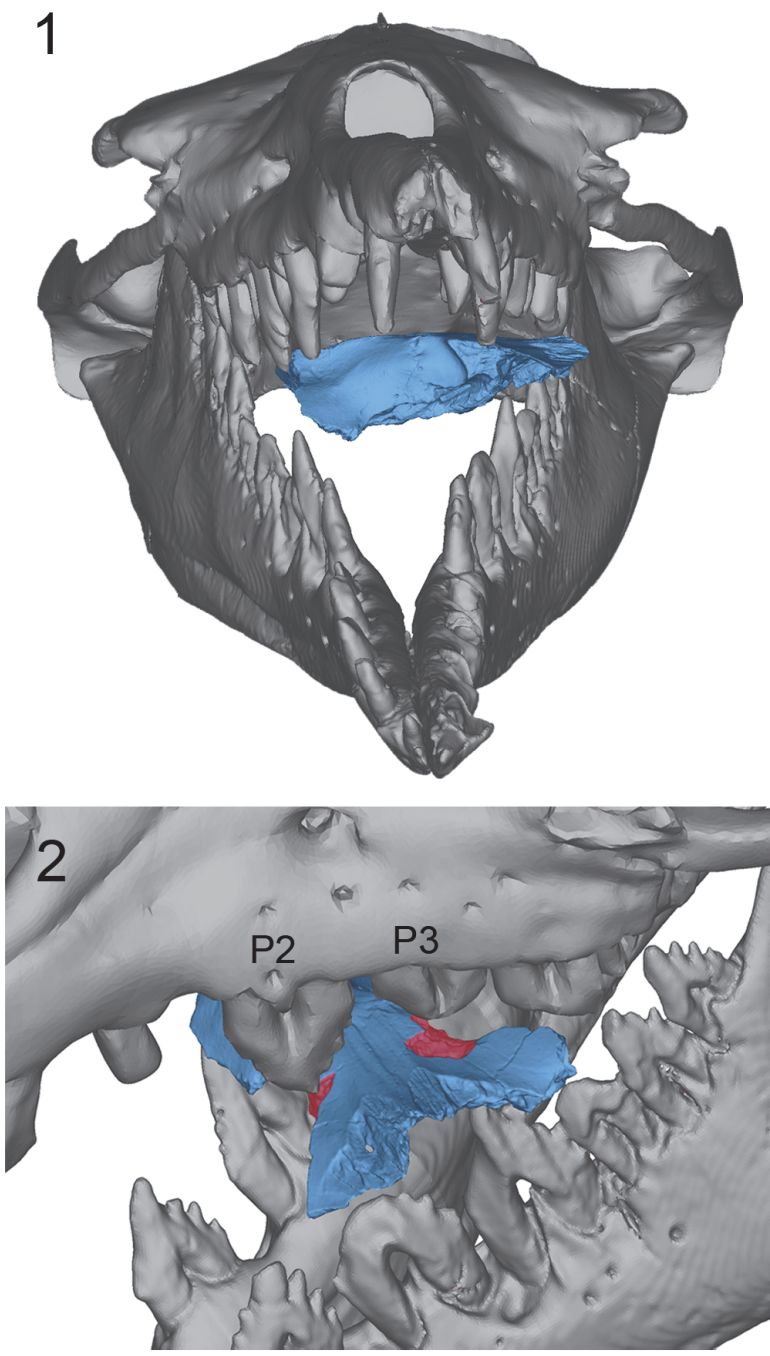

FIGURE 5. Placement of 3D digital surface model of juvenile Dorudon atrox specimen UM 94811 (blue) into the mouth of an adult Basilosaurus isis (reconstruction of $\mathrm{WH}-74$, gray). 5.1 , best fit of teeth to bone modifications in frontal view; 5.2, same in left lateral view. Directions are given with respect to the skull of $B$. isis; bone modifications are highlighted in red.

Eocene of Egypt. However, crocodile bite marks differ from the marks of pointed teeth observed on the $D$. atrox remains in the following aspects:

Crocodile bite marks are typically bisected due to bicarination of the teeth, i.e., a sharp ridge that runs down the complete anterior and posterior sides of each monocuspid tooth, and across the tip in unworn teeth (Njau and Blumenschine, 2006). Unworn or slightly worn central cusps of cheek teeth of $B$. isis also bear ridges on their anterior and posterior faces, but these ridges are relatively blunt. Bone modifications 1-5 on UM 94814 are oval in outline with small round projections at the
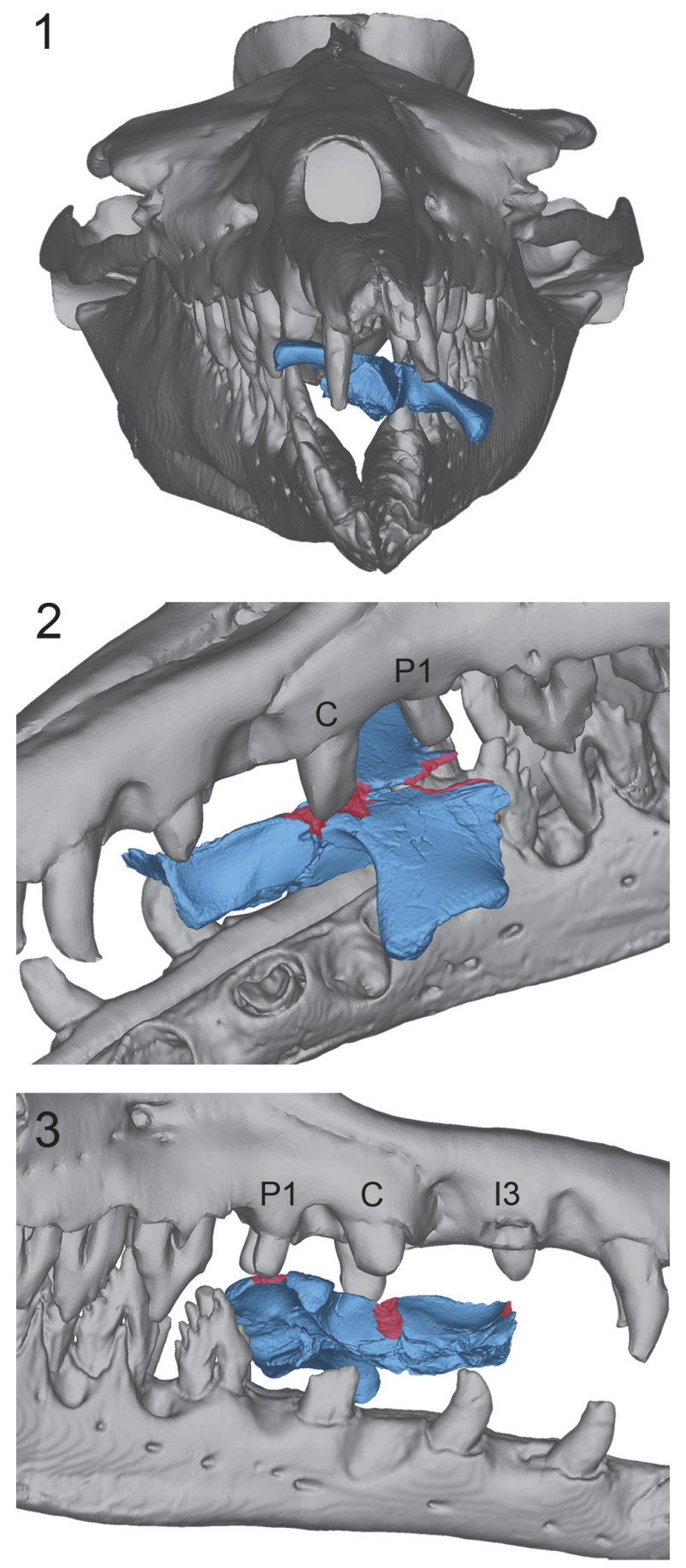

FIGURE 6. Placement of 3D digital surface model of juvenile Dorudon atrox specimen UM 100142 (blue) into the mouth of an adult Basilosaurus isis (reconstruction of $\mathrm{WH}-74$, gray). 6.1 , best fit of teeth to bone modifications in frontal view; 6.2, same in left lateral view; 6.3 , same in right lateral view. Directions are given with respect to the skull of $B$. isis; bone modifications are highlighted in red. 
ends of their long axes, reflecting the presence of blunt rather than sharp ridges. No true bisection like that figured by Njau and Blumenschine (2006) was observed.

In addition to bite marks caused by pointed cusps, UM 94814 also has bite marks that are deeper and larger, and have irregular edges and outlines (bone modifications 6-8). These marks cannot be attributed to crocodylians, but fit the cheek teeth of $B$. isis.

Small mounds in the centers of bite marks, like those seen in modifications 2 and 3 on UM 94814 have not been reported for crocodile bite marks. A possible explanation for these mounds might be the thin enamel of $B$. isis. Thin enamel on the tips of tooth cusps was worn away easily, exposing softer dentin that wears more quickly than enamel, so that a ring of enamel was formed during an initial stage of wear (cf. right $\mathrm{P} 2$ of $\mathrm{WH}-$ 74; Figure 2).

Another form of bite mark that is distinctive for crocodiles are hook scores. These are parabolic in shape and are produced during the so-called "death roll" that crocodiles perform in order to disintegrate their prey (Njau and Blumenschine, 2006). No hook scores were found on any of the studied $D$. atrox specimens.

In addition to crocodiles, many predatory and scavenging shark species are known from the middle to late Eocene of the Fayum area of Egypt, among them the very large Carcharocles sokolowi that has teeth of up to $9.5 \mathrm{~cm}$ in height (Case and Cappetta, 1990; Underwood et al. 2011). Case studies revealed that bites of modern large sharks usually leave a series of tooth impressions arranged in a curvilinear pattern, sets of linear score marks, or sharp cuts in hard or rigid objects including bone (e.g., Byard et al., 2000; Lowry et al., 2009; Meel, 2009). Cuts and scrapes have previously been reported as evidence for shark attacks on cetaceans in the fossil record (e.g., Bianucci et al., 2010; Bianucci and Gingerich, 2011), but no characteristic cuts and scrapes were found on the specimens of juvenile $D$. atrox studied here, and bites marks do not appear to be arranged in a distinct curvilinear shape. Therefore, sharks are excluded as a potential tracemaker.

Boessenecker and Perry (2011) described circular bite marks on fossil bones of juvenile fur seals from the Mio-Pliocene that resemble the marks seen on these juvenile $D$. atrox crania, especially bone modification 1 on UM 100139 (Figure 1.3) and bone modification 1 on UM 94811 (Figure 1.5) in terms of shape and depth, and bite marks 1-5 of UM 94814 (Figure 1.2) in size. Boessenecker and Perry (2011) attributed the bite marks they observed to a mammalian predator (pilot whale, walrus, otariid, or terrestrial carnivore), and also excluded sharks as potential producers, based on shape, size, and distribution of the bite marks.

The only carnivorous mammals in the Birket Qarun and Gehannam Formations of Egypt that are large enough to have potentially produced the bite marks on juvenile $D$. atrox skulls analyzed here are adult $B$. isis and adult $D$. atrox. Although adult body length of $D$. atrox (5 m; Uhen, 2004) is only about a third of that of $B$. isis (16 m; WH-74), the skulls of both species do not differ much in length. Adult skull length of $B$. isis $(\mathrm{WH}-74)$ is about $113 \mathrm{~cm}$, whereas that of $D$. atrox is $95 \mathrm{~cm}$ (Uhen, 2004). Figure 7 shows the crania of both species drawn to scale. Consequently, the distances between individual teeth of $D$. atrox in the upper tooth row are only slightly shorter than or approximately equal to those observed in $B$. isis. However, the distance between bone modifications 1 and 2 that presumably belong to the same set of marks on UM 100139 (108.5 mm) approximates the distance between $\mathrm{I} 3$ and $\mathrm{C}$ of $B$. isis but exceeds any distance between individual teeth in the tooth row of $D$. atrox (see Figure 7 for measurements).

Additionally, some of the bite marks, e.g., bite mark 1 on UM 94811 (Figure 1.5), are impressions of very blunt, worn teeth. Tooth wear to this degree implies extensive breakage of cusps and further erosion. Some teeth of $D$. atrox show extensive wear. However, the extent of breakage, spalling of flakes of enamel and dentin and further abrasion that would result in this kind of extreme blunting of cusps is known in B. isis (Fahlke et al., 2010) but has not been documented for $D$. atrox thus far.

Ancalecetus simonsi, another basilosaurid archaeocete represented by a single individual from the Birket Qarun Formation of Wadi Al-Hitan, shows extensive tooth wear on its lower teeth and on the few known isolated upper teeth, but its upper dentition is poorly preserved (Gingerich and Uhen, 1996), and little can be said about the spacing of its upper teeth. It appears that $A$. simonsi was about the size of $D$. atrox (Gingerich, 2008) or slightly smaller (Gingerich and Uhen, 1996) and therefore can probably also be excluded as the producer of the bite marks discussed in this paper.

Besides vertebrate predators and scavengers, other feeding and dwelling organisms can potentially make traces that indent or penetrate bone tissue. Belaústegui et al. (2012) classified and 

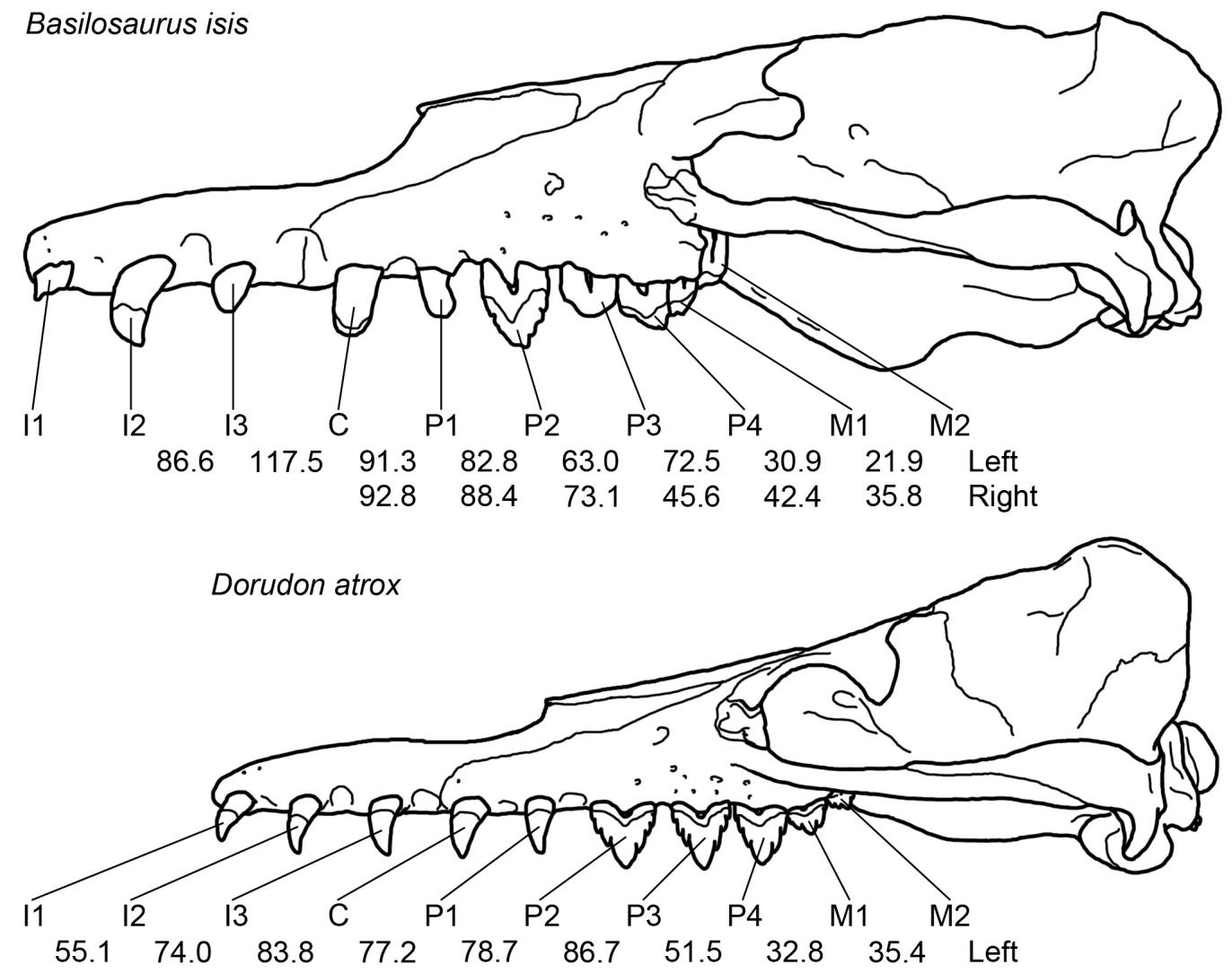

FIGURE 7. Crania of adult Basilosaurus isis and adult Dorudon atrox drawn to scale, with measurements of distances between teeth (in $\mathrm{mm}$ ). Skull length of $B$. isis is approximately $113 \mathrm{~cm}$; skull length of $D$. atrox is approximately $95 \mathrm{~cm}$. The drawing and measurements of $B$. isis are based on $\mathrm{WH}-74 ; D$. atrox is redrawn and mirrored after Uhen (2004), with measurements of UM 101222.

compared a variety of traces on fossil marine tetrapod bones. Clavate borings with smooth walls like those described by the authors for bivalves were not found on the juvenile $D$. atrox skulls studied here, and neither radula marks nor star-shaped gnawing marks characteristic of gastropods and echinoids, respectively, were observed.

Esperante et al. (2009) assumed that a decapod crustacean was responsible for bone modifications they observed on a fossil mysticete skeleton from southern Spain. The bone modifications presented in this paper, however, do not have regular edges like those described by Esperante et al. (2009), and no shallow grooves were observed.

Osedax worm borings consist of individual canals that lead from an aperture into the bone, where they expand to chambers. Extensive subsurface erosion may then lead to the collapse of superficial bone tissue (Higgs et al., 2012). No such structures are visible on the $D$. atrox remains either.

In conclusion, an adult $B$. isis was likely the tracemaker that produced the bite marks on $D$. atrox specimens UM 94814, UM 100139, UM 94811, and UM 100142.

\section{Circumstances of Bite Mark Infliction}

Based on the presence of sharp edges and lack of callus formation on the bone, Uhen (2004) identified the bite marks on UM 94811, 94814, and 100139 as evidence of lethal predation on calves of $D$. atrox. Reviewing the evidence presented in this study, Uhen's (2004) findings are confirmed here in that no indication of callus formation was found. The same is true for additional bone modifications on the above-mentioned specimens and on UM 100142.

Uhen (2004) also notes that the bite marks he described could alternatively have been inflicted 
during scavenging. Looking at the evidence presented in this study, the scrape between bite marks 3 and 4 on UM 94814 and the scrape on the left side of UM 100142 may be viewed as evidence of adjustment of the prey in the mouth and therefore potentially indicate predation on a moving (i.e., living) individual. However, it must be taken into consideration that these scrapes could also have been produced during violent manipulation (e.g., tossing, jerking) of the already deceased juveniles.

All $D$. atrox specimens included in this study represent very young juveniles, as can be inferred from their stage of tooth eruption and incomplete fusion of bony sutures (Uhen, 2000, 2004). It is interesting to note that all known bite marks have been found on juvenile specimens of $D$. atrox and none have thus far been found on adult individuals. If scavenging is included as a hypothesis for how bite marks were inflicted, the question remains why juveniles but not adults would have been scavenged upon.

Comparing $B$. isis to the killer whale (Orcinus orca) that regularly includes large marine mammals, including other cetaceans, in its diet (e.g., Werth, 2000), it is not unlikely that $B$. isis might have employed both predation and scavenging, since, besides active predation, scavenging on fish discarded by fishermen and cetacean carcasses produced by whalers has also been observed in killer whales (Couperus, 1994; Whitehead and Reeves, 2005).

In one case (UM 94814), a first capture followed by readjustment of the prey in the mouth and a more forceful second bite are implied by the position and depth of the bite marks, and two (ore more) consecutive bites in unknown order might have caused the damage to UM 100139 and possibly UM 100142. Uhen (2004) suggested a mechanism of prey capture with the anterior teeth and subsequent disintegration with the posterior teeth for $D$. atrox. A comparable procedure might be assumed for $B$. isis here. Generally, bite marks were apparently produced by all teeth between the positions $13 / i 3$ and $P 4 / p 3$, without engagement of the molars of $B$. isis.

In this study, the best fit of bite marks on juvenile skulls of $D$. atrox with the dentition of an adult $B$. isis was obtained when a bite from the left side (three out of four cases) or from the front (one out of four cases) was simulated. This distribution might not be a coincidence, since archaeocete whales have asymmetrical skulls (Fahlke et al., 2011), and thus their visual field might not be the same on both sides. If predation took place, approaching the prey from the left side might have been advantageous. Sample size, however, is too small to support this idea statistically.

When preying on other cetaceans like sperm whales (Physeter macrocephalus) or gray whales (Eschrichtius robustus), killer whales have been observed holding prey individuals by the flukes or flippers and dragging them out of the safety of their pod or into deeper water. Killer whales also circle and ram their prey and bite pieces out of living individuals (e.g., Pitman et al., 2001; Barrett-Lennard et al., 2011) and also have been observed drowning a grey whale calf by biting it across the snout and subsequently holding it under water, its blowhole inverted (Barrett-Lennard et al., 2011).

It is possible that adult $B$. isis bit $D$. atrox calves across the head and held them under water, and drowning might be taken into consideration as a possible mode of killing in archaeocetes. However, the rostrum of $B$. isis is much longer and narrower compared to that of a killer whale so that it appears unlikely that $B$. isis was able to ram its prey like killer whales do. A study of the bite force of $B$. isis using finite element analysis is currently being conducted and will shed further light on the capabilities of $B$. isis as a potential predator of marine mammals. Whether or not $B$. isis hunted in groups cannot be inferred from present evidence.

The cranial remains of $D$. atrox that have bite marks do not show significant corrosion and have not been found in close association with $B$. isis remains. This means that they do not represent gut contents, and, although $B$. isis obviously bit $D$. atrox across the head, the heads themselves were likely not consumed. This inferred behavior would again resemble that of killer whales that are known to disintegrate and bite pieces out of larger prey, consuming preferably soft parts (e.g., Werth, 2000; Pitman et al., 2001; Barrett-Lennard et al., 2011).

Although both $B$. isis and $D$. atrox occur in the same marginal marine deposits of the Tethys Sea, $B$. isis was apparently more common in the deeper-water environments at Wadi Al-Hitan, while $D$. atrox was more abundant in environments closer to the shoreline (Peters et al., 2009). Furthermore, both juveniles and adults of $D$. atrox are known, whereas no juvenile of $B$. isis has been found to date. Does this mean that $B$. isis lived and bred further offshore, and adult $B$. isis invaded the shallow-marine habitats of $D$. atrox, possibly in order to feed on their young? This scenario used to be mere speculation. The evidence presented in this study, however, shows that $B$. isis predation on juvenile $D$. atrox is very well possible. 


\section{Diet of Basilosaurus isis}

Stomach contents of $B$. cetoides from the late Eocene of North America have been identified as remains of fishes and sharks (Swift and Barnes, 1996), and the authors assumed that fish was the typical food of archaeocetes. This assumption gains support from stomach contents of $D$. atrox, consisting of various kinds of fish (Uhen, 2004). However, this study shows that at least Basilosaurus isis did not, or at least not exclusively, consume fish but very likely also marine mammals.

Although the exact body size of the living juvenile $D$. atrox cannot be estimated precisely due to allometric growth, the size of the cranial pieces analyzed here (widths of the frontal shields of over $20 \mathrm{~cm}$ ) and adult body lengths of $D$. atrox of about $5 \mathrm{~m}$ (Uhen, 2004) imply that these Dorudon calves were significantly longer than the $50 \mathrm{~cm}$ body length estimated for sharks and fishes consumed by B. cetoides (Swift and Barnes, 1996).

These large-scale regional dietary differences between members of the genus Basilosaurus are reminiscent of dietary specialization in genetically and morphologically distinct populations of the modern killer whale. In the northeastern Pacific, resident killer whales are known to have specialized on (salmonid) fish, transient killer whales feed on mammals, and offshore killer whales have been shown to consume sharks (Ford et al., 2011). Comparable dietary specializations are also known from killer whale populations in the North Atlantic (Foote et al., 2009; Foote, 2011) and the Antarctic (Pitman, 2011).

Ford et al. (2011) attributed abrasive tooth wear in offshore killer whales to denticles embedded in shark skin. Similarly abrasive wear on the teeth of $B$. isis, in addition to the breakage and spalling of enamel and dentin that has been attributed to bone crushing (Fahlke et al., 2010), might possibly be a result of the consumption of sharks that were sympatric with $B$. isis in the middle to late Eocene (e.g., Case and Cappetta, 1990; Underwood et al., 2011). An analysis of the tooth wear of $B$. cetoides and comparison with that of $B$. isis would shed further light on this issue, but is beyond the scope of this paper.

\section{CONCLUSIONS}

Revision of known bite marks and analysis of additional bone modifications on cranial remains of juvenile $D$. atrox included optical inspection and measurements of the modifications, creation of imprints of $B$. isis tooth casts in modeling clay, and digital placement of 3D surfaces of the cranial remains of $D$. atrox into the mouth of an adult $B$. isis. Results show that the dentition of $B$. isis fits the bite marks and that juvenile $D$. atrox were predominantly bitten across the head from a left lateral position and sometimes adjusted in the mouth between bites. Other predators and scavengers, like sharks and crocodiles, or boring organisms could be ruled out as the tracemaker.

In conclusion, $B$. isis was likely a predator that included juvenile $D$. atrox in its diet. Comparing $B$. isis with the modern killer whale (Orcinus orca), beheading and drowning of $D$. atrox calves are potential killing scenarios. Scavenging is also possible.

The diet of Basilosaurus and apparent dietary differences within the genus (medium-sized fish in the North American form vs. archaeocetes in the Tethyan form) resemble those known in modern killer whales. Thus, dietary specialization similar to that seen in modern cetaceans already existed among middle-to-late Eocene archaeocetes. $B$. isis is the only archaeocete known to date that possibly preyed on other cetaceans.

\section{ACKNOWLEDGMENTS}

I thank P. Gingerich (University of Michigan, Ann Arbor) for access to the fossil material and for reading an earlier version of this manuscript together with M. Voss (Museum für Naturkunde, Berlin). W. Sanders and J. Klausmeyer (University of Michigan, Ann Arbor) are thanked for fossil preparation and production of casts. I am thankful to R.C. Welsh, H. DeMarsh, and M. Muck (University of Michigan, Ann Arbor) for CT scanning of WH-74 and CT image processing, and R.C. Welsh in particular for permission to use the 3D surfaces that were extracted from his scans. I also thank E. Maslowski, S. O'Grady, and S. Heise (University of Michigan 3D Lab, Ann Arbor) for access to and help with surface scanning equipment and 3D software, G. Gunnell (Duke Lemur Center, Durham) for helpful insight and comments, and two anonymous reviewers for their constructive suggestions. Funding was provided by a Feodor Lynen Fellowship of the Alexander von Humboldt Foundation.

\section{REFERENCES}

Andrews, C.W. 1906. A Descriptive Catalogue of the Tertiary Vertebrata of Fayum, Egypt. British Museum of Natural History, London. 
Barrett-Lennard, L.G., Matkin, C.O., Durban, J.W., Saulitis, E.L., and Ellifrit, D. 2011. Predation on gray whales and prolonged feeding on submerged carcasses by transient killer whales at Unimak Island, Alaska. Marine Ecology Progress Series, 421:229241.

Belaústegui, Z., de Gibert, J.M., Domènech, R., Muñiz, F., and Martinell, J. 2012. Clavate borings in a Miocene cetacean skeleton from Tarragona (NE Spain) and the fossil record of marine bone bioerosion. Palaeogeography, Palaeoclimatology, Palaeoecology, 323-325:68-74.

Bianucci, G. and Gingerich, P.D. 2011. Aegyptocetus tarfa, n. gen. et sp. (Mammalia, Cetacea), from the middle Eocene of Egypt: clinorhynchy, olfaction, and hearing in a protocetid whale. Journal of Vertebrate Paleontology, 31:1173-1188.

Bianucci, G., Sorce, B., Storai, T., and Landini, W. 2010. Killing in the Pliocene: shark attack on a dolphin from Italy. Palaeontology, 53:457-470.

Boessenecker, R.W. and Perry, F.A. 2011. Mammalian bite marks on juvenile fur seal bones from the Late Neogene Purisma Formation of central California. Palaios, 26:115-120.

Byard, R.W., Gilbert, J.D., and Brown, K. 2000. Pathologic features of fatal shark attacks. American Journal of Forensic Medicine and Pathology, 21:225-229.

Case, G.R. and Cappetta, H. 1990. The Eocene selachian fauna from the Fayum Depression in Egypt. Palaeontographica Abt. A, 212:1-30.

Clementz, M.T., Goswami, A., Gingerich, P.D., and Koch, P.S. 2006. Isotopic records from early whales and sea cows: contrasting patterns of ecological transition. Journal of Vertebrate Paleontology, 26:355-370.

Couperus, A.S. 1994. Killer whales (Orcinus orca) scavenging on discards of freezer trawlers north east of the Shetland Islands. Aquatic Mammals, 20:47-51.

Esperante, R., Muñiz Guinea, F., and Nick, K.E. 2009. Taphonomy of a Mysticeti whale in the lower Pliocene Huelva Sands Formation (Southern Spain). Geologica Acta, 7:489-505.

Fahlke, J.M., Wood, A.R., and Gingerich, P.D. 2010. Chewing movement and tooth function in Basilosaurus isis (Mammalia, Cetacea) based on digital analysis of wear facets. SVP 2010 Program and Abstract Book:86A.

Fahlke, J.M., Gingerich, P.D., Welsh, R.C., and Wood, A.R. 2011. Cranial asymmetry in Eocene archaeocete whales and the evolution of directional hearing in water. Proceedings of the National Academy of Sciences USA, 108:14545-14548.

Foote, A.D. 2011. North Atlantic killer whales. Whalewatcher: Journal of the American Cetacean Society, 40(1):30-32.

Foote, A.D., Newton, J., Piertney, S.B., Willerslev, E., and Gilbert, T.P. 2009. Ecological, morphological and genetic divergence of sympatric North Atlantic killer whale populations. Molecular Ecology, 18:52075217.
Ford, J.K.B., Ellis, G.M., Matkin, C.O., Wetklo, M.H., Barrett-Lennard, L.G., and Withler, R.E. 2011. Shark predation and tooth wear in a population of northeastern Pacific killer whales. Aquatic Biology, 11:213-224.

Fordyce, R.E. and Barnes, L.G. 1994. The evolutionary history of whales and dolphins. Annual Review of Earth and Planetary Sciences, 22:419-455.

Fordyce, R.E. and de Muizon, C. 2001. Evolutionary history of cetaceans: a review, p. 169-233. In Mazin, J.M. and de Buffrénil, V. (eds.), Secondary Adaptation of Tetrapods to Life in Water. Verlag Dr. Friedrich Pfeil, München.

Geisler, J.H. and Uhen, M.D. 2003. Morphological support for a close relationship between hippos and whales. Journal of Vertebrate Paleontology, 23:991996.

Gingerich, P.D. 1992. Marine mammals (Cetacea and Sirenia) from the Eocene of Gebel Mokattam and Fayum, Egypt: stratigraphy, age, and paleoenvironments. University of Michigan Papers on Paleontology, 30:1-84.

Gingerich, P.D. 2003. Land-to-sea transition in early whales: evolution of Eocene Archaeoceti (Cetacea) in relation to skeletal proportions and locomotion of living semiaquatic mammals. Paleobiology, 29:429454.

Gingerich, P.D. 2005. Cetacea, p. 234-252. In Rose, K.D. and Archibald, J.D. (eds.), Placental Mammals: Origin, Timing, and Relationships of the Major Extant Clades. Johns Hopkins University Press, Baltimore.

Gingerich, P.D. 2008. Early evolution of whales: A century of research in Egypt, p. 107-124. In Fleagle, J.G. and Gilbert, C.C. (eds.), Elwyn Simons: A Search for Origins. Springer, New York.

Gingerich, P.D. and Uhen, M.D. 1996. Ancalecetus simonsi, a new dorudontine archaeocete (Mammalia, Cetacea) from the early late Eocene of Wadi Hitan, Egypt. Contributions from the Museum of Paleontology, the University of Michigan, 29:359-401.

Gingerich, P.D., Wells, N.A., Russell, D.E., and Shah, S.M.I. 1983. Origin of whales in epicontinental remnant seas: new evidence from the early Eocene of Pakistan. Science, 220:403-406.

Gingerich, P.D., ul-Haq, M., Zalmout, I.S., Khan, I.H., and Malkani, M.S. 2001. Origin of whales from early artiodactyls: hands and feet of Eocene Protocetidae from Pakistan. Science, 293:2239-2242.

Gingerich, P.D., ul-Haq, M., von Koenigswald, W., Sanders, W.S., Smith, B.H., and Zalmout, I.S. 2009. New Protocetid whale from the middle Eocene of Pakistan: birth on land, precocial development, and sexual dimorphism. PLOS ONE, 4(2):e4366.

Higgs, N.D., Little, C.T.S., Glover, A.G., Dahlgren, T.G., Smith, C.R., and Dominici, S. 2012. Evidence of Osedax worm borings in Pliocene $(\sim 3 \mathrm{Ma})$ whale bone from the Mediterranean. Historical Biology, 24:269-277. 
Johnston, C. and Berta, A. 2010. Comparative anatomy and evolutionary history of suction feeding in cetaceans. Marine Mammal Science, 27:493-513.

Lowry, D., de Castro, A.L.F., Mara, K., Whitenack, L.B., Delius, B., Burgess, G.H., and Motta, P. 2009. Determining shark size from forensic analysis of bite damage. Marine Biology, 156:2483-2492.

Luo, Z. and Gingerich, P.D. 1999. Terrestrial Mesonychia to aquatic Cetacea: transformation of the basicranium and evolution of hearing in whales. University of Michigan Papers on Paleontology, 31:1-98.

Meel, B.L. 2009. Shark attacks on the Transkei coast of South Africa: A case report. African Journal of Primary Health Care \& Family Medicine, 1(1):Art.48. doi: 10.4102/phcfm.v1i1.48

Njau, J.L. and Blumenschine, R.J. 2006. A diagnosis of crocodile feeding traces on larger mammal bone, with fossil examples from the Plio-Pleistocene Olduvai Basin, Tanzania. Journal of Human Evolution, 50:142-162.

Nummela, S., Thewissen, J.G.M., Bajpai, S., Hussain, S.T., and Kumar, K. 2004. Eocene evolution of whale hearing. Nature, 430:776-778.

O'Leary, M.A. and Uhen, M.D. 1999. The time of origin of whales and the role of behavioral changes in the terrestrial-aquatic transition. Paleobiology, 25:534-556.

Peters, S.E., Antar, M.S.M., Zalmout, I.S., and Gingerich, P.D. 2009. Sequence stratigraphic control on preservation of late Eocene whales and other vertebrates at Wadi Al-Hitan, Egypt. Palaios, 24:290-302.

Pitman, R.L. 2011. Antarctic killer whales: top of the food chain at the bottom of the world. Whalewatcher: Journal of the American Cetacean Society, 40(1):3945.

Pitman, R.L., Ballance, L.T., Mesnick, S.J., and Chivers, S.J. 2001. Killer whale predation on sperm whales: observations and implications. Marine Mammal Science, 17:494-507.

Roe, L.J., Thewissen, J.G.M., Quade, J., O'Neill, J.R., Bajpai, S., Sahni, A., and Hussain, S.T. 1998. Isotopic approaches to understanding the terrestrial-tomarine transition of the earliest cetaceans, p. 399422. In Thewissen, J.G.M. (ed.), The Emergence of Whales: Evolutionary Patterns in the Origin of Cetacea. Plenum Press, New York.
Spoor, F., Bajpai, S., Hussain, S.T., Kumar, K., and Thewissen, J.G.M. 2002. Vestibular evidence for the evolution of aquatic behaviour in early cetaceans. Nature, 417:163-166.

Swift, C.C. and Barnes, L.G. 1996. Stomach contents of Basilosaurus cetoides: implications for the evolution of cetacean feeding behavior, and the evidence for vertebrate fauna of epicontinental Eocene seas. The Paleontological Society Special Publications, 8:380.

Thewissen, J.G.M., Williams, E.M., Roe, L.J., and Hussain, S.T. 2001. Skeletons of terrestrial cetaceans and the relationship of whales and artiodactyls. Nature, 413:277-281.

Thewissen, J.G.M., Sensor, J., Clementz, M., and Bajpai, S. 2011. Evolution of dental wear and diet during the origin of whales. Paleobiology, 37:655-669.

Uhen, M.D. 2000. Replacement of deciduous first premolars and dental eruption in archaeocete whales. Journal of Mammalogy, 81:123-133.

Uhen, M.D. 2004. Form, function, and anatomy of Dorudon atrox (Mammalia, Cetacea): an archaeocete from the middle to late Eocene of Egypt. University of Michigan Papers on Paleontology, 34:1-222.

Uhen, M.D. 2007. Evolution of marine mammals: back to sea after 300 million years. Anatomical Record, 290:514-522.

Uhen, M.D. 2010. The origin(s) of whales. Annual Review of Earth and Planetary Sciences, 38:189219.

Underwood, C.J., Ward, D.J., King, C., Antar, S.M., Zalmout, I.S., and Gingerich, P.D. 2011. Shark and ray faunas in the middle and late Eocene of the Fayum area, Egypt. Proceedings of the Geologists' Association, 122:47-66.

Werth, A. 2000. Feeding in marine mammals, p. 487526. In Schwenk, K. (ed.), Feeding: Form, Function, and Evolution in Tetrapod Vertebrates. Academic Press, San Diego.

Whitehead, H. and Reeves, R. 2005. Killer whales and whaling: the scavenging hypothesis. Biology Letters, $1: 415-418$. 